\title{
Vaccine Hesitancy Among U.S. Military Service Members: Contributing Factors and Operational Impacts on the Great Power Competition
}

\author{
Mary Wootan Holst and Cameron Carlson
}

\begin{abstract}
The COVID-19 Pandemic has presented the United States military with a unique challenge to maintain a forward presence in support of national security while adhering to critical COVID safety practices. Evidence-based COVID safety practices such as social distancing, sheltering at home, and now vaccinating are critical in protecting service members' health. Simultaneously, these safety measures are challenging for the U.S. military because service members live and work in close quarters, options for telework are limited, and units must continue to execute worldwide deployments. A Pandemic milestone occurred in December 2020 when the FDA approved the first of several COVID-19 vaccinations under an Emergency Use Authorization (EUA). Force-wide vaccination is critical for the U.S. military to return to unimpeded operations and safeguard units from debilitating outbreaks. While military member vaccination is traditionally compulsory for all Food and Drug Administration (FDA)approved vaccinations, service members have had the rare choice to accept or decline the EUA COVID-19 vaccine until full FDA approval is granted. The vaccination decisions of individual service members have had significant operational, financial, and logistical impacts throughout the U.S. military. The prevention and mitigation of outbreaks across military units have required significant person-hours and financial obligations to ensure units can operate and deploy safely and on schedule. This paper discusses the historical context and current motivations behind military vaccine-hesitancy, broad operational impacts, and recommendations on addressing vaccine-hesitancy within the U.S. armed forces.
\end{abstract}

Keywords: military, vaccinations, vaccine-hesitancy, non-compliance, mRNA, COVID-19 


\section{La vacilación de las vacunas entre los miembros del servicio militar de los EE. UU.: Factores contribuyentes e impactos operativos en la competencia de las grandes potencias}

\section{RESUMEN}

La pandemia COVID-19 ha presentado al ejército de los Estados Unidos un desafío único para mantener una presencia avanzada para apoyar la seguridad nacional mientras se adhiere a las prácticas de seguridad críticas de COVID. Las prácticas de seguridad de COVID basadas en evidencia, como el distanciamiento social, el refugio en el hogar y ahora la vacunación, son fundamentales para proteger la salud de los miembros del servicio. Al mismo tiempo, estas medidas de seguridad son un desafío para el ejército de los EE. UU. Porque los miembros del servicio viven y trabajan en lugares cerrados, las opciones para el teletrabajo son limitadas y las unidades deben continuar ejecutando despliegues en todo el mundo. Un hito pandémico se produjo en diciembre de 2020 cuando la FDA aprobó la primera de varias vacunas COVID-19 bajo una Autorización de uso de emergencia (EUA). La vacunación en toda la fuerza es fundamental para que el ejército de los EE. UU. Regrese a sus operaciones sin obstáculos y proteja a las unidades de brotes debilitantes. Si bien la vacunación de miembros militares es tradicionalmente obligatoria para todas las vacunas aprobadas por la Administración de Alimentos y Medicamentos (FDA), los miembros del servicio han tenido la rara opción de aceptar o rechazar la vacuna EUA COVID-19 hasta que se otorgue la aprobación completa de la FDA. Las decisiones de vacunación de los miembros individuales del servicio han tenido importantes impactos operativos, financieros y logísticos en todo el ejército de los EE. UU. La prevención y mitigación de brotes en las unidades militares ha requerido importantes horas de trabajo y obligaciones financieras para garantizar que las unidades puedan operar y desplegarse de manera segura y según lo programado. Este documento analiza el contexto histórico y las motivaciones actuales detrás de la vacilación militar a las vacunas, los impactos operativos generales y las recomendaciones para abordar la vacilación a las vacunas dentro de las fuerzas armadas de los EE. UU.

Palabras clave: militares, vacunas, reticencia a las vacacunas, incumplimiento, mRNA, COVID-19 


\section{美国兵役人员的疫苗犹豫：促进性因素 和对大国竞争产生的操作性影响}

\section{摘要}

2019冠状病毒病（COVID-19）大流行为美国军方就保持领先 位置以支持国家安全同时遵守关键的COVID安全实践一事提 出了独特挑战。基于证据的COVID安全实践, 例如保持社交 距离、居家和接种疫苗, 对保护服役人员的健康而言是关键 的。同时, 这些安全措施对美国军方具有挑战性, 因为服役 人员在近距离的营房中工作和生活, 远程工作选项受限, 并 且部队必须持续执行全球部署。2020年12月迎来了大流行里 程碑一食品药品监督管理局（FDA）通过一项紧急使用授权

(EUA)，批准了首个可用的COVID-19疫苗。以部队为单位的 疫苗接种对美国军事重返不受限的行动并保护部队不受病毒 爆发而言是关键的。尽管军队成员的疫苗接种在传统意义上 必须适用于所有经FDA批准的疫苗, 但服役人员在FDA完全批 准疫苗之前有权选择接受或拒绝接种EUA COVID-19疫苗, 这一 选择是罕见的。服役人员的个人疫苗接种决定对美国军方产 生了显著的操作性影响、金融影响和后勤影响。预防和缓解 病毒在军事部队爆发, 要求相当多的人力和金融义务, 确保 部队能按计划进行安全操作和部署。本文探讨了军方疫苗犹 豫 (vaccine-hesitancy) 背后的历史情境和当前激励、广泛 的操作性影响, 并就应对美国武装力量的疫苗犹豫一事提出 建议。

关键词: 军方, 疫苗, 疫苗犹豫, 不服从, mRNA, 2019冠状 病毒病

\section{Introduction and}

\section{COVID-19 Explained}

The novel coronavirus SARSCoV-2, or COVID-19, was first 1 documented in Wuhan province, China, in Fall 2019, when an uniden- tified individual was hospitalized for Pneumonia-like symptoms that were later attributed to COVID-19. ${ }^{1}$ Coronaviruses are positive-stranded Ribonucleic acid (RNA) viruses that traditionally reside in animals, though in recent history SARS and MERS coronavirus-

1 “Immunization Coverage." World Health Organization. World Health Organization. Accessed August 6, 2021. https://www.who.int/news-room/fact-sheets/detail/immunization-coverage. 
es were found and treated in humans. While the origin of COVID-19 is not confirmed, a leading theory is that the virus spread from an animal to human host at a wet (fresh or live meat) market in the Wuhan province in China in Fall 2019. ${ }^{2}$ In this theory, natural mutations would have enabled COVID-19's initial zoonotic jump and set the stage for further transmissions of COVID-19 through human-to-human contact. Common to RNA viruses such as the common cold or influenza, transmission is primarily through aerosolization of fluids via coughing or sneezing, and close contact dramatically increases incident of transmission. ${ }^{2}$ The infection cycle can last up to 14 days, with common symptoms including shortness of breath, dry cough, fevers, chills, and loss of smell. A COVID-19 infection is often asymptomatic, creating a public health concern when asymptomatic COVID-positive persons unwittingly become a vector. The virus can remain asymptomatic during the initial infection, transmission window, or for the duration of the infection, which complicates carrier identification and close contacts.

\section{Vaccination Types and Vaccine- Induced Immunopathology}

he COVID-19 pandemichas had
crippling social and economic
impacts throughout the world. The two options to achieve herd immunity were mass infection or vaccines, therefore vaccines were the lynchpin to slow the COVID-19 outbreak and returning nations to social and economic normalcy. ${ }^{3}$ At the height of the efforts to create a SARS-CoV-2 vaccine, approximately 200 different types of vaccines were in development. ${ }^{4}$ As of 20 July 2021, the FDA approved three vaccines under the United States FDA Emergency Use Authorization, Food, Drug, and Cosmetic Act, Section 564: Moderna, Pfizer, and Johnson \& Johnson. As discussed below, two are messenger (mRNA) vaccines, and one is a non-replicating viral vector vaccine. All mitigate the threat of an individual becoming ill with severe symptoms from COVID-19, and studies show they are 95\% effective at protecting against all known variants of COVID-19, including the Delta variants. ${ }^{5}$

2 Alliance for Securing Democracy. 2021. "Influence-enza: How Russia, China, and Iran Have Shaped and Manipulated Coronavirus Vaccine Narratives.” Securing Democracy. https://se curingdemocracy.gmfus.org/russia-china-iran-covid-vaccine-disinformation/.

3 "Herd Immunity and COVID-19 (Coronavirus): What You Need to Know." Mayo Clinic. Mayo Foundation for Medical Education and Research, June 9, 2021. https://www.mayoclinic.org/diseas es-conditions/coronavirus/in-depth/herd-immunity-and-coronavirus/art-20486808.

4 Payne, Daniel C., Sarah E. Smith-Jeffcoat, and Gosia Nowak. 2020. "SARS-CoV-2 Infections and Serologic Responses from a Sample of U.S. Navy Service Members - USS Theodore Roosevelt, April 2020." MMWR Morbidity and Mortality Weekly Report 69 (23): 714-721. https://www.ncbi. nlm.nih.gov/pmc/articles/PMC7315794/

5 Payne, Daniel C., Sarah E. Smith-Jeffcoat, and Gosia Nowak. 2020. "SARS-CoV-2 Infections and Serologic Responses from a Sample of U.S. Navy Service Members - USS Theodore Roosevelt, April 2020." MMWR Morbidity and Mortality Weekly Report 69 (23): 714-721. https://www.ncbi. 


\section{RNA and Non-Replicating Viral Vector Vaccines}

COVID-19 is a positive-stranded RNA virus, and following its discovery in early 2020, the world began a race to develop a vaccine to inoculate against it. Moderna and Pfizer, both mRNA vaccines, were two of the initial vaccines approved against COVID-19. An mRNA vaccine creates immunity based on the premise that a host's antigen-presenting cells recognize vaccine-introduced mRNA and uses it as a blueprint to produce a humoral and cellular immune response. ${ }^{6}$

Scientists have been manipulating mRNA since the early 1990s when the first in Vitro (the growth of cells outside of a host, in such a medium as a petri dish or test tube) was accomplished. These cells were injected into mice and protein production could be seen. ${ }^{7}$ This production of proteins proved that this type of manipulation of cells could be used to produce more advanced techniques in fighting pathogens. However, over the past ten years, the mRNA vaccine and therapies have proven to be more beneficial than their DNA-based counterparts. This is based on the fact that mRNA vaccines have a higher safety profile than DNA vaccines as there are no live or attenuated viruses contained in them which minimizes risk of inadvertent infection. Also, mRNA vaccines are much more effective as various genetic modifications can be made to suit nearly any application required. ${ }^{8}$ In 2021 , multiple mRNA vaccine platforms have been created and validated in the studies of immunogenicity and efficacy. In addition, the engineering of the mRNA sequence has allowed for the development of synthetic mRNA that is highly translatable for modern vaccines such as the ones manufactured by Moderna and Pfizer to fight the COVID-19 virus. ${ }^{9}$ mRNA vaccines are relatively fast to produce as they utilize single proteins rather than complex replicating or non-replicating viruses, which facilitates rapid, mass distribution, critical during the ongoing Pandemic.

\section{Non-Replicating Viral Vector Vaccines}

Non-replicating viral vector (NRVV) vaccines utilize a non-pathogenic virus

nlm.nih.gov/pmc/articles/PMC7315794/

6 Sabin Vaccine Institute and The Aspen Institute. 2020. "Meeting the Challenge of Vaccination Hesitancy." Sabin-Aspen report 2020, (May). https://assets.aspeninstitute.org/content/uploads/2020/06/sabin-aspen-report-2020_meeting_the_challenge_of_vaccine_hesitancy.pdf? $\mathrm{ga}=2.242091585 .236896274 .1591219234-1140465311.1590185549$.

7 Pardi, Norbert, Michael J. Hogan, Frederick W. Porter, and Drew Weissman. 2018. "mRNA vaccines - a new era in vaccinology." Nature Reviews Drug Discovery 17 (January): 261-279. https:// doi.org/10.1038/nrd.2017.243.

8 Ibid.

9 Coughlan, Lynda. 2020. "Factors Which Contribute to the Immunogenicity of Non-replicating Adenoviral Vectored Vaccines." Frontiers in Immunology, (May). https://doi.org/10.3389/fimmu.2020.00909. 
as a transport medium to introduce a highly attenuated virus to a host's immune system and elicit the desired immune response. ${ }^{10}$ In the COVID-19 pandemic, Johnson \& Johnson was developed with NRVV technology utilizing recombinant adenovirus with multiple layers of viral glycoprotein from the COVID-19 virus. Unlike the mRNA vaccines which required two doses up to 21 days apart, Johnson \& Johnson only requires a one-time dose which was a clinical advantage because compliance was not complicated by a return visit.

NRVV vaccination development has been in use since 1937, when scientists first used a recombinant process for an attenuated Yellow Fever vaccination. ${ }^{11}$ One of the popular viruses now used to develop this style of vaccine is Vesicular Stomatitis Virus (VSV). VSV is an ideal virus for this vaccine method because it does not have a pathogenic effect on the human body yet still elicits a robust immune response from the body. NRVV is popular in immunogenicity and in the development of vaccines due to their relative ease of manipulation, safety, and efficacy. ${ }^{12}$ The use of non-replicating viral vectors as a vaccine platform has several advantages over other types of vaccine procedures such as, recombinant protein, and/or inactivated particles. ${ }^{13}$ Unlike mRNA vaccines, viral vectored vaccines retain some characteristics of a live attenuated vaccine, such as their ability to enter target cells and facilitate antigen (Ag) expression and subsequent Ag-presentation in vivo (inside of a living host), but contain additional safety features. ${ }^{14}$ In recent history, the non-replicating viral vector Ebola vaccine was used successfully during the 2014-2016 outbreaks in Africa.

\section{Vaccination Protocols in the United States Military}

0 ervice members are especially susceptible to the spread of infectious diseases due to their close quarters working environment and duties being incompatible with telework or sequestering at home. For example, sailors spend prolonged time embarked on ships or submarines, airmen work in the confines of cockpits or cargo holds, and soldiers live and work in small forward operating bases. This creates a difficult

10 Cole, Jared P., and Kathleen S. Swendiman. 2014. Mandatory Vaccinations: Precedent and Current Laws. N.p.: Congressional Research Service. RS21414.

11 Coughlan, Lynda. 2020. "Factors Which Contribute to the Immunogenicity of Non-replicating Adenoviral Vectored Vaccines." Frontiers in Immunology, (May). https://doi.org/10.3389/fimmu.20 20.00909 .

12 Coughlan, Lynda. 2020. "Factors Which Contribute to the Immunogenicity of Non-replicating Adenoviral Vectored Vaccines." Frontiers in Immunology, (May). https://doi.org/10.3389/fimmu.20 20.00909 .

13 Ibid.

14 Forgey, Quint. 2021. "Pentagon: 70 percent of service members have received first dose of Covid vaccine." Politico, July 16, 2021. https://www.politico.com/news/2021/07/16/militarycoronavirus-vaccine-499822. 
environment to control a virus unless vaccinations are widely distributed, and public health measures are strictly maintained. Therefore, the U.S. Military has a stringent vaccination program in which certain vaccinations are mandated as a condition of service.

The Department of Defense (DoD) administers 17 mandatory vaccines to all service members on active or reserve duty. The military maintains the legal authority to mandate general and specialized vaccines to all service members and tailor additional vaccine requirements based on military occupation. The DoD Directive 6200.04 delineates how and when these vaccines are given. Per DOD Directive 6200.04, the $\mathrm{DoD}$ requires service members to be immunized against diseases, including tetanus, diphtheria, influenza, hepatitis A, measles, mumps, rubella, polio, and yellow fever. ${ }^{15}$ In certain situations such as religious objections, vaccination requirements can theoretically be waived, though there is precedent through cases such as United States $v$. Chadwell where service members' religious objections to vaccinations were denied. In United States v. Chadwell, two U.S. Marines cited religious belief when refusing smallpox, typhoid, paratyphoid, and influenza vaccines.
When brought before the Navy Board of Review court (now the Navy-Marine Corps Court of Criminal Appeals), it stated that religious beliefs were not above military orders and that "to permit this would be to make the professed doctrines of religious belief superior to military orders, and in effect to permit every soldier to become a law unto himself." ${ }^{16}$ Additionally, even if granted, waivers can be revoked as necessary to accomplish a critical mission.

In considering the COVID-19 vaccination, the DoD Immunization Program Instruction does not address vaccines issued under an Emergency Use Act (EUA) issued by the Director of Health and Human Services (HHS) ${ }^{17}$ A declaration of a EUA allows the use of unapproved medical products (i.e., vaccines) or unapproved use of approved medical products in an emergency to diagnose, treat, or prevent serious or life-threatening diseases or conditions during a declared public health emergency. ${ }^{18} \mathrm{~A}$ vaccine can be issued on a voluntary basis under a EUA when HHS declares that a public health emergency exists. This issuance or declaration resulting in an EUA does not mandate a vaccine for any American citizen, including the military, as it is unapproved or has not gone full licensure.

15 Cole, Jared P., and Kathleen S. Swendiman. 2014. Mandatory Vaccinations: Precedent and Current Laws. N.p.: Congressional Research Service. RS21414.

16 Ibid

17 U.S. Food and Drug Administration. 2021. "Emergency Use Authorization." U.S. Food and Drug Administration. https://www.fda.gov/emergency-preparedness-and-response/mcm-legal-regulato ry-and-policy-framework/emergency-use-authorization.

18 South, Todd. 2021. "Troops who refused anthrax vaccine paid a high price." Military Times. https:// www.militarytimes.com/news/pentagon-congress/2021/06/17/troops-who-refused-anthrax-vac cine-paid-a-high-price/. 


\section{Historical Implications for Vaccine-Hesitancy}

W hile COVID-19 vaccinations were rapidly developed, concerns among the public about the vaccine's safety profile lead to growing COVID-19 vaccine-hesitancy. Vaccine hesitancy has been a critical consideration within public health since the 1100s. At this time, primitive vaccination was the variolation technique, which saw the introduction of a small amount of infected material (e.g. blood, scabs, pus) into a healthy host to produce a minor but survivable infection and provide immunity. ${ }^{19}$ This method was used in the pediatric population in Turkey, Africa, China, and Europe to combat Smallpox. This method of "vaccination" through variolation was utilized until 1879 when Louis Pasteur developed the first attenuated vaccine for Chicken Cholera. After a favorable outcome, this technique was utilized again in 1885 to vaccinate against Rabies. ${ }^{20}$

Initial vaccination hesitancy among the general public was fueled by early vaccines released without appropriate quality or safety standards. For example, in 1901, 13 children died after inoculation with a tetanus-contaminated Diphtheria vaccine. ${ }^{21}$ It was not until 1910 that the medical profession adopted stringent vaccination guidelines, education requirements, and qualification and licensing standards. These early unfortunate outcomes during the development of vaccines most likely still inform vaccine-hesitancy today.

When considering the roots of vaccination hesitancy, vaccination programs in public health must also be examined from a socio-cultural standpoint. Many Americans view the current healthcare system as a consumerist system that prioritizes health care on a profit-driven model, where treatment is encouraged to create income for providers. ${ }^{22}$ This may lead to concerns about whether a patient truly benefits from treatment or is recommended for profit alone. Also, patients who once subscribed to a paternalistic medical model in which medical professionals directed healthcare are now shifting to an informed patient model where shared decision-making processes and second opinions are encouraged. While patient ownership over their health is valuable and critical, information-seeking behavior may lead to the introduction of unverified or false med-

19 U.S. Food and Drug Administration. 2021. "Emergency Use Authorization.” U.S. Food and Drug Administration. https://www.fda.gov/emergency-preparedness-and-response/mcm-legal-regulato ry-and-policy-framework/emergency-use-authorization.

20 Kasper, M. R., J. R. Geibe, C. L. Sears, A. J. Riegodedios, T. Luse, A. M. Von Thun, M. B. McGinnis, et al. n.d. "An Outbreak of Covid-19 on an Aircraft Carrier." N Engl J Med 2020 Dec 17;383(25):24172426. doi: 10.1056/NEJMoa20193752020 Dec 17;383(25):2417-2426.

21 Ibid.

22 Dube, Eve, Caroline Laberge, Paul Bramadat, Real Roy, and Julie A. Bettinger. 2013. "Vaccine Hesitancy." Human Vaccines and Immunotheraputics 9, no. 8 (April): 1762-1773. https://doi.org/10.4161/ hv.24657. 
ical information through open sources such as the internet or social media. This unfiltered access to information and social media platforms has given many anti-vaccination forums a prominent voice and may influence a recent rise in vaccination non-compliance. In addition, these forums and voices often provide non-evidenced-based or biased literature on the potentially harmful effects of vaccines and vaccine-treatable diseases. ${ }^{23}$

\section{US military COVID-19 Vaccine-Hesitancy Impact on The Great Power Competition}

$\mathrm{I}$ $\mathrm{n}$ the competition of power, the country that can place its competitors on a loose footing makes the rules. Traditionally, competition between the world powers takes place in an environment with freedom of movement and the ability to congregate military units for decisive, large scale action. What happens when a worldwide pandemic, such as COVID-19, comes to the stage, halts international movement, and disperses troops? Whereas the great powers traditionally focus on adversary deployments and geospatial movements, COVID-19 changed the landscape of threats and turned focus inward. This undermined operational schedules of militaries throughout the world and potentially limited the assets a country could commit to an adversary action. Service member vaccine-hesitancy, which further prevents forces from achieving group immunity, is an additional obstacle forcing countries to rethink how they will effectively counter a foreign adversary in the ongoing Pandemic environment.

It can be a reasonable assumption that if a majority of a nation's military refused to vaccinate, they would be at risk of exploitation from other nations due to their inability to respond effectively to threats. In the current digital landscape of social media, 24/7 news cycle, and the race of nations to "control the narrative," propaganda and misinformation reign supreme, and vaccine diplomacy leads the charge. Vaccine narratives naturally developed during the race to develop the first effective vaccine. ${ }^{24}$ For example, Russia stated that the Sputnik V vaccine was superior to others while spreading misinformation or "cherry-picking" information to discredit other nations. This biased information can be utilized to influence adversary military servicemembers to question vaccine safety and efficiency, increasing vaccine-hesitancy within the ranks and crippling the response capabilities of the great powers.

Had the COVID-19 pandemic occurred during a time of high conflict, it is reasonable to assume that the nation

23 Dube, Eve, Caroline Laberge, Paul Bramadat, Real Roy, and Julie A. Bettinger. 2013. "Vaccine Hesitancy." Human Vaccines and Immunotheraputics 9, no. 8 (April): 1762-1773. https://doi.org/10.4161/ hv.24657.

24 Alliance for Securing Democracy. 2021. "Influence-enza: How Russia, China, and Iran Have Shaped and Manipulated Coronavirus Vaccine Narratives.” Securing Democracy. https://securingdemocra cy.gmfus.org/russia-china-iran-covid-vaccine-disinformation/. 
that responded with strict health protection measures and evidence-based education to encourage high vaccination compliance would ensure rapid return to full operational capacity and potentially military superiority. Therefore, the nation that educates and encourages its service members towards high vaccination compliance is more apt to win a conflict based on personnel numbers and morale alone.

\section{Economic Impacts of Vaccine- Hesitancy}

As a pandemic progresses, the economic toll will rise. As of 3 April 2020, in only a few short months, the COVID-19 pandemic cost the globe $\$ 3.8$ trillion and took 147 million jobs. ${ }^{25}$ This downward economic trend will affect virtually all aspects of a government, including the military. As lockdowns and quarantines were implemented, the government was still responsible for critical services requiring in-person work to continue functioning, such as national defense. Training, material maintenance, and readiness of the United States military and conceivably all militaries in the world suffered as personnel could not return to work safely. For forces afloat, COVID-19 restrictions forced them to remain at sea burning expensive fuel. Ashore, units were forced into expensive sequestering options such renting out hotel rooms for prolonged periods.
Military person-hours once reserved for planning and strategy were exponentially dedicated to COVID-19 mitigation. Furthermore, to adhere to COVID-19 safety guidance, military units operated below ideal manning numbers, compromising efficiency and effectiveness. A military ceases to operate effectively without key personnel to provide logistics services, conduct maintenance, or support other functions.

A pandemic, once fully formed, can be potentially stopped in a finite number of ways: contact tracing, isolation or lockdowns, and vaccination. ${ }^{26}$ However, for prolonged pandemics that continue for months, or longer in the case of COVID-19, vaccination becomes the critical route to a return to control the return full operational capacity. Vaccine-hesitancy directly contributes to the prolongation of a pandemic and the effects detailed above, therefore negatively impacting the defense of all nations. The safety of a country is placed at risk from both threats at home and aboard as the militaries lose the agility and capability to respond effectively to external threats.

\section{Military COVID-19 Vaccination Response}

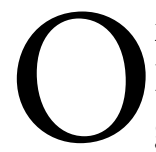
n 11 December 2020, the U.S. FDA provided the first emergency use authorization (EUA)

25 Manfred, Lenzen, Li Mengyu, Malik Arunima, Francesco Pomponi, and Ya-Yen Sun. 2020. “Global socio-economic losses and environmental gains from the Coronavirus pandemic." PLOS One 15 (7). https://journals.plos.org/plosone/article?id=10.1371/journal.pone.0235654.

26 Guest, Jodie L., Carlos d. Rio, and Travis Sanchez. 2020. “The Three Steps Needed to End the COVID-19 Pandemic: Bold Public Health Leadership, Rapid Innovations, and Courageous Political Will." JMIR Publications 6, no. 2 (April). 10.2196/19043. 
for the Pfizer-BioNTech vaccine against COVID-19 in persons 16 years or older. Shortly after, additional vaccines were granted emergency use authorization. These vaccines were initially prioritized within the military to select groups, including health care personnel (HCP) and deploying service members. Among 1,331,523 active component service members serving during December 2020, 361,538 (27.2\%) initiated COVID-19 vaccination by 12 March 2021, and among the 110,456 active component HCP included in this number, 60,763 (55.0\%) initiating a COVID-19 vaccine series. ${ }^{27}$

As discussed, due to the nature of the EUA, vaccine initiation among U.S. military service members will remain voluntary until the FDA provides full approval for the vaccination. While there is historical precedent for the DoD administering unapproved, investigational drugs and vaccinations to military members, under the EUA the COVID-19 vaccination is not compulsory for service members. Service members' response to receiving a voluntary vaccine has fallen across a spectrum from acceptance to hesitancy. The vaccine-acceptance contingent includes active demand of vaccines received by an informed public, and passive acceptance (compliance by a public that yields to a perceived recommendation or social pressures)..$^{28}$ Meanwhile, vaccine-hesitant groups include those persons who want to delay or decline certain or all vaccinations. The vaccineacceptance group may include all of the $27.2 \%$ of servicemembers to receive the vaccine at the first opportunity and follow-on service members who received the vaccine as it first became available to them. This group may be motivated by active demand, ambivalence, or compliance despite concerns due to social pressure. The vaccine-hesitant contingent is defined by "individuals [who] may refuse some vaccines, but agree to others; they may delay vaccines or accept vaccines according to the recommended schedule, but be unsure in doing so." ${ }^{29}$ In the U.S. military, this group initially encompassed $33 \%$ of military personnel who by February 2021 reported they would decline vaccination, and by July 2021, the Pentagon reported that $67 \%$ of U.S. service members were vaccinated. ${ }^{30}$ Three fundamental mentalities that lead to military vaccine-hesitancy are discussed below.

27 Immunization Action Coalition. 2021. "Vaccine Timeline." Historic Dates and Events Related to Vaccines and Immunization. https://www.immunize.org/timeline/.

28 Guest, Jodie L., Carlos d. Rio, and Travis Sanchez. 2020. “The Three Steps Needed to End the COVID-19 Pandemic: Bold Public Health Leadership, Rapid Innovations, and Courageous Political Will." JMIR Publications 6, no. 2 (April). 10.2196/19043.

29 Dube, Eve, Caroline Laberge, Paul Bramadat, Real Roy, and Julie A. Bettinger. 2013. "Vaccine Hesitancy." Human Vaccines and Immunotheraputics 9, no. 8 (April): 1762-1773. https://doi.org/10.4161/ hv.24657.

30 Forgey, Quint. 2021. "Pentagon: 70 percent of service members have received first dose of Covid vaccine." Politico, July 16, 2021. https://www.politico.com/news/2021/07/16/military-coronavirusvaccine-499822. 
A preliminary study on vaccine disparities in COVID-19 vaccine initiation among select active-duty service members elucidated some common demographics for the vaccine-acceptance and vaccine-hesitant groups. For the vaccination acceptance group, socioeconomic demographics included "increasing age, greater education levels, and higher rank," and the study noted, "Asian/Pacific Islanders were the only race/ethnicity group to have had a higher rate of initiation...compared to non-Hispanic Whites." ${ }^{31}$ Meanwhile, the vaccination hesitant socioeconomic demographics included "women serving in the military, younger troops, and service members in lower ranks and with less education," and the study noted "a $29 \%$ lower odds of having received the vaccination among non-Hispanic Black U.S. participants in comparison to non-Hispanic Whites, which was similar between the general community and among health care workers." ${ }^{32}$

Notably, the vaccine-hesitancy in the military population is similar to those reported in the general U.S. population. Surveys conducted by the CDC from September 2020 to December 2020 showed $32.1 \%$ of all adults among most sociodemographic groups displayed vaccination non-intent (defined as not intending to receive a COVID-19 vaccination). Those persons more likely to report lack of intent were "younger adults, women, non-Hispanic black (Black) persons, adults living in nonmetropolitan areas, and adults with lower educational attainment, with lower income, and without health insurance."33

\section{Concerns Leading to Service Members Vaccination Hesitancy}

Vaccine-hesitant service members who did not initiate vaccination or refused vaccination are motivated by complex personal factors such as values, education, experiences, and religious beliefs that cannot easily be generalized. Though more studies are required to enumerate the reasons behind military-specific vaccination hesitancy, as with other vaccine-hesitancy trends, it has been observed to reflect the general population. Among U.S. adults surveyed in December who did not intend to take the vaccine, the leading reasons were concerns about side effects and safety of the COVID-19 vaccine $(29.8 \%)$, delaying vaccination to evaluate if the vaccine is safe and consider receiving it later (14.5\%), lack of

31 Lang, Michael A., Shauna Stahlman, Natalie Y. Wells, and Et Al. 2021. "Disparities in COVID-19 Vaccine Initiation and Completion Among Active Component Service Members and Health Care Personnel, 11 December 2020-12 March 2021." MEDICAL SURVEILLANCE MONTHLY REPORT 28, no. 4 (APR): 2-9. PMID: 33975434.

32 Ibid.

33 Nguyen, Kimberly H., Anup Srivastav, Hilda Razzaghi, Walter Williams, Megan C. Lindley, Cynthia Jorgensen, Neetu Abad, and James A. Singleton. 2021. "COVID-19 Vaccination Intent, Perceptions, and Reasons for Not Vaccinating Among Groups Prioritized for Early Vaccination - United States, September and December 2020." Morbidity and Mortality Weekly Report 70 (6): 217-222. https://www.cdc.gov/mmwr/volumes/70/wr/mm7006e3.htm\#suggestedcitation. 
trust in the government (12.5\%), and concern that COVID-19 vaccines were developed too quickly (10.4\%). ${ }^{34}$ Below, three notable factors of vaccine-hesitancy in the military population are discussed: COVID-19 vaccination safety, general vaccination distrust, and general non-compliance.

A leading concern for the vaccine-hesitant population specific to the COVID-19 vaccinations is lack of confidence in COVID-19 vaccine safety due to factors such as the speed at which the vaccination was created, implications of the emergency use authorization, and vaccination side effects. Distrust regarding novel vaccination is rooted in recent history when from 1998-2004, the military ran a mandatory anthrax vaccination program in which the nonFDA-approved vaccine Anthrax Vaccine Adsorbed (AVA) was distributed to service members. Due to the approval status and concerns over side effects, hundreds of service members refused the vaccine, and punitive repercussions ranged from public shaming to jail time and dishonorable discharges. ${ }^{35}$ Ultimately, the program was halted after a federal judge found insufficient approval for AVA to be used against inhalation anthrax and, furthermore, that service- members should be provided informed consent and not be required to take experimental (non-FDA approved) drugs. ${ }^{36}$ When weighing service member's personal liberties against the operational impact of vaccination hesitancy, it is important to consider recent occurrences like this where some service members were punished for refusing an unauthorized vaccine. COVID-19 has established a new precedent in which service members would not be forced to take a non-FDA-approved vaccine. For vaccine-hesitant persons whose concerns center around the EUA, the eventual full FDA approval of current COVID-19 vaccinations may prove to be sufficient and lead to vaccination.

Side effects are also a leading concern among vaccine-hesitant service members, as safety concerns may include rare side effects such as blood clots, anaphylaxis, and myocarditis. One study may seem to validate these concerns due to the identification of rare myocarditis vaccine side-effects in 23 previously healthy military members within four days of a COVID-19 vaccine (Pfizer or Moderna), which was documented as "substantially higher than the expected number." However, researchers assured that "concerns about rare

34 Nguyen, Kimberly H., Anup Srivastav, Hilda Razzaghi, Walter Williams, Megan C. Lindley, Cynthia Jorgensen, Neetu Abad, and James A. Singleton. 2021. "COVID-19 Vaccination Intent, Perceptions, and Reasons for Not Vaccinating Among Groups Prioritized for Early Vaccination - United States, September and December 2020." Morbidity and Mortality Weekly Report 70 (6): 217-222. https://www.cdc.gov/mmwr/volumes/70/wr/mm7006e3.htm\#suggestedcitation.

35 Roos, Robert. 2003. "Judge orders DoD to stop requiring anthrax shots." Center for Infectious Disease Research \& Policy. https://www.cidrap.umn.edu/news-perspective/2003/12/judge-or ders-dod-stop-requiring-anthrax-shots.

36 Roos, Robert. 2003. "Judge orders DoD to stop requiring anthrax shots." Center for Infectious Disease Research \& Policy. https://www.cidrap.umn.edu/news-perspective/2003/12/judge-or ders-dod-stop-requiring-anthrax-shots. 
adverse events following immunization should not diminish overall confidence in the value of vaccination." ${ }^{37}$ Vaccine-hesitancy service members may also include women and men who cite fertility concerns, which became widespread after Dr. Michael Yeadon and Dr. Wolfgang Wodrag filed a petition with the European Medicine Agency citing safety concerns with the SARS-CoV-2 vaccine. These concerns included a negative impact on female fertility because the vaccine induces an autoimmune reaction against syncytin-1 protein, which is involved in placenta formation..$^{38}$ These concerns have since been found to lack evidence, and in a systematic review published in the Fertility and Sterility international journal, a systematic review found no credible evidence linking COVID-19 vaccine with female infertility. Also, the authors of the review argued that men should receive the vaccine due to infertility risks in contracting actual COVID-19 disease. Ultimately, the potential systemic and long-term effects of COVID-19 disease on male and female infertility have not been fully understood. ${ }^{39}$

A separate concern for some members of the military vaccine-hesitant contingent is a baseline distrust of vaccinations that will not be alleviated with full FDA approval or further testing of the COVID-19 vaccine. This group may have complied with other mandatory vaccine requirements due to the compulsory nature of many military vaccinations, but they have had to suspend their concerns and discomfort to remain military eligible. This concern echos a growing movement of vaccine-hesitancy globally. The world's vaccination rates have declined, evidenced by a global coverage decline from $86 \%$ in 2019 to $83 \%$ in 2020 among a growing concern around the purpose and efficacy of vaccinations. ${ }^{40}$ As discussed earlier, this global decline in vaccine uptake may be driven by various factors, including misinformation within popular media campaigns against vaccination or now-debunked vaccination myths such as the link between vaccinations and autism. This global decline may also have been impacted by restrictive safety measures that disrupted the distribution of vaccines during the COVID-19 pandemic.

Lastly, an unmeasurable subset

37 Montgomery, Jay, and Margaret Ryan. 2021. "Myocarditis Following Immunization With mRNA COVID-19 Vaccines in Members of the US Military." 10.1001/jamacardio.2021.2833 ed. JAMA Cardiology.

38 Watson, Rachel E., Taylor B. Nelson, and Albert L. Hsu. 2021. "Fertility Considerations: The COVID-19 disease may have a more negative impact than the COVID-19 vaccine, especially among men." (March). https://www.fertstertdialog.com/posts/fertility-considerations-the-covid19-disease-may-have-a-more-negative-impact-than-the-covid-19-vaccine-especially-amongmen?room_id=871-covid- 19 .

39 Ibid.

40 "WHO and UNICEF Warn of a Decline in Vaccinations During Covid-19." World Health Organization. World Health Organization. Accessed August 6, 2021. https://www.who.int/news/item/1507-2020-who-and-unicef-warn-of-a-decline-in-vaccinations-during-covid-19. 
of the vaccine-hesitant military population may refuse vaccination from an inherent desire to non-conform. The foundation of military success is built on uniformity and compliance, therefore service members approach many decision points with a fixed outcome. For example: where to live, what to eat, even medical decisions such as vaccinations or do not resuscitate (DNR) orders. The opportunity to make personal decisions does not exist as commonly as it does in the civilian population. This leads to a subset of the population who are displaying early vaccination refusal and motivated by the novel ability to decline otherwise mandatory healthcare. Appeasing the desire to non-conform with more personal freedom may require a cultural approach not feasible in the military, which fosters and depends upon a uniformed environment and benefits from safety measures such as mass vaccination.

\section{Discussion and Way Forward}

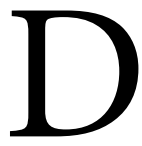
ue to the massive operational impact of vaccinations on military operations and national security, military leadership must understand and urgently address vaccine-hesitancy within their ranks. As demonstrated on USS Harry S Truman when a crew of 5,461 sailors and airmen returned home with zero cases of COVID-19, prevention from outbreak across military units is possible yet requires detailed coordination and individual commitment to best practices for disease prevention. ${ }^{41}$ On the other hand, USS Theodore Roosevelt demonstrates the devastating effect an infectious disease outbreak can have on a crew, platform, and mission. The USS Roosevelt was deployed shortly after USS Harry S Truman and was forced to make port in Guam after a COVID-19 outbreak spread through the crew. Out of a crew of approximately 5,000 people, 1,271 crew members were tested positive for SARS-CoV-2, with 1000 infections first identified within five weeks of the first confirmed infection..$^{42}$ The close berthing and working quarters in the shipboard environment facilitated the rapid viral spread, illustrating why compliance with infectious diseases prevention methods such as masks, social distancing, and eventually vaccines is critical. ${ }^{43}$ Ultimately, both vessels were forced to alter operational plans, placing a tremendous financial burden on the government and impacting national security posturing abroad. USS Roosevelt was forced to conduct an extended stay in Guam to address the outbreak, limiting the ability to remain at sea to

41 Bigornia, Veronica E. 2021. "U.S. Navy Aircraft Carrier Prevents Outbreak at Sea in Midst of COVID-19." Mil Med. 186 (7-8): 178-180. doi: 10.1093/milmed/usab107.

42 Kasper, M. R., J. R. Geibe, C. L. Sears, A. J. Riegodedios, T. Luse, A. M. Von Thun, M. B. McGinnis, et al. n.d. "An Outbreak of Covid-19 on an Aircraft Carrier." N Engl J Med 2020 Dec 17;383(25):24172426. doi: 10.1056/NEJMoa20193752020 Dec 17;383(25):2417-2426.

43 Payne, Daniel C., Sarah E. Smith-Jeffcoat, and Gosia Nowak. 2020. "SARS-CoV-2 Infections and Serologic Responses from a Sample of U.S. Navy Service Members - USS Theodore Roosevelt, April 2020." MMWR Morbidity and Mortality Weekly Report 69 (23): 714-721. https://www.ncbi. nlm.nih.gov/pmc/articles/PMC7315794/. 
support a forward presence critical to the U.S. mission and homeland defense. This is just one example of the profound operational impact COVID-19 has had on national security and emphasizes the importance of thoughtfully addressing vaccine-hesitancy.

While there is no single approach to addressing vaccination hesitancy in the military, a leading strategy is individual and unit-wide education on vaccinations for service members. The front line of this education must be military physicians, physician assistants, nurses, and medical professionals who are trusted and often personally known by the service members they are counseling. By facilitating this education through a trusted agent, military leadership establishes a voice in vaccination education, which can be dominated by non-evidence-based information predominately promulgated through social media, news outlets, or throughout the internet. When developing strategies to address vaccine-hesitancy, it may be valuable to reflect on the demographics of vaccine-hesitant service members discussed previously to tailor education to their specific concerns and reasons for vaccine-hesitancy.

The military may also consider addressing historical vaccination campaigns and experimental studies that have caused concern amongst the ranks, for example, the recent Anthrax cam- paign discussed earlier or the infamous Tuskegee Study of Untreated Syphilis in the Negro Male conducted between 1932 to 1972 . Following the public exposure of the Tuskegee study, the longterm effects on the Black community were erosion of trust in physicians and the medical system which decreased health-seeking behavior and healthcare utilization for black men. ${ }^{44} \mathrm{~A}$ convergence of the broken trust caused by these two campaigns may be responsible for the highest vaccination hesitancy group of non-Hispanic black (Black) service members. Of concern, several studies found similar trends in vaccination intent and low likelihood of receiving a COVID-19 vaccine among groups disproportionately affected by COVID-19, including Black persons. ${ }^{45}$ Distrust of the government is a leading concern for anti-vaccination campaigns in and out of the military, and understanding and addressing these concerns directly may encourage restoration of trust.

Of note, there is a growing conversation around implementing mandatory COVID-19 vaccination across the military before full FDA approval. Some great power nations have also implemented mandatory vaccinations for specific groups or individuals based on their occupations with concerning results. For example, areas of Russia and China implemented mandatory vaccinations and punitive measures for individ-

44 Newkirk II, Vann R. 2016. “A Generation of Bad Blood.” The Atlantic, JUNE 17, 2016. https://www. theatlantic.com/politics/archive/2016/06/tuskegee-study-medical-distrust-research/487439/.

45 Manfred, Lenzen, Li Mengyu, Malik Arunima, Francesco Pomponi, and Ya-Yen Sun. 2020. "Global socio-economic losses and environmental gains from the Coronavirus pandemic." PLOS One 15 (7). https://journals.plos.org/plosone/article?id=10.1371/journal.pone.0235654. 
uals who choose not to receive the vaccine. ${ }^{46,47}$ For example, in Wanning, a city in the southern providence of Hainan, China, residents were threatened with loss of government benefits or access to public transportation if they refused vaccinations. This causes widespread criticism, and the Chinese government had to step in over concern over a possible backlash from the population. ${ }^{48}$ While the governments of Russia and China promoted the benefits of their nation's vaccine, they also battle internal division and the spread of misinformation, even from their own public health divisions. Only approximately 11 percent of Russians have been vaccinated against COVID-19, which may be influenced by distrust built by forced vaccinations. ${ }^{49}$ U.S. military leaders must consider that this tension created by vaccine mandates can have dire consequences for national security if it feeds into government distrust and fuels anti-vaccination movements. ${ }^{50}$ While the recent call for mandating the EUA COVID-19 vaccinations throughout the military may be operationally favorable, forced vaccination will not only disregard hesitancy concerns, it may even perpetuate reasons for vaccination hesitancy.

Additional factors outside the military's control that may mitigate COVID-19 vaccination hesitancy are the advancement from a EUA to full FDA approval for COVID-19 vaccinations and simply consistent vaccination promotion over time. Multiple studies have shown a decrease in vaccine-hesitancy over time, including a study of vaccine-hesitant among groups prioritized for vaccines that showed an increase in vaccination intent across all surveyed adults and priority groups by approximately 10 percentage points over four months while vaccination non-intent decreased by six percent and across most socio-demographic groups. ${ }^{51}$ This decrease in non-intent may be explained by a patient's ability to see the occurrences of side effects (a leading initial vaccination concern) over time or the loss of novelty. While

46 Litvinova, Daria. "Russia Mandates Vaccinations for Some as Virus Cases Surge." AP NEWS. Associated Press, June 25, 2021. https://apnews.com/article/europe-russia-health-coronavirus-pandemicbusiness-42d0c14f0545371e16a360b677cb4c38.

47 Che, Claire, ed. "China Calls For Halt to Mandatory Vaccines Amid Inoculation Push." Bloomberg.com. Bloomberg, April 11, 2021. https://www.bloomberg.com/news/articles/2021-04-12/chi na-calls-for-halt-to-mandatory-vaccines-amid-inoculation-push.

48 Ibid

49 Litvinova, D. "Coronavirus pandemic Russia mandates vaccinations for some." Associated Press, June 25, 2021. https://apnews.com/article/europe-russia-health-coronavirus-pandemic-busi ness-42d0c14f0545371e16a360b677cb4c38.

50 Ibid

51 Nguyen, Kimberly H., Anup Srivastav, Hilda Razzaghi, Walter Williams, Megan C. Lindley, Cynthia Jorgensen, Neetu Abad, and James A. Singleton. 2021. "COVID-19 Vaccination Intent, Perceptions, and Reasons for Not Vaccinating Among Groups Prioritized for Early Vaccination - United States, September and December 2020." Morbidity and Mortality Weekly Report 70 (6): 217-222. https://www.cdc.gov/mmwr/volumes/70/wr/mm7006e3.htm\#suggestedcitation. 
waiting for vaccine-hesitancy to resolve is not in-of-itself a strategy, it may be helpful to expect that in the specific circumstance of the COVID-19 EUA approval and rapid vaccine production, some service members may only need time to receive anecdotally and study evidence to trust the vaccine.

The U.S. military has successfully and historically made COVID-19 vaccination available to every service mem- ber, significantly decreasing the barrier to military-wide vaccination. However, to enable the U.S. military to execute its national security mission and maintain footing in the Great Power competition, leaders must understand the factors leading to vaccine hesitancy and address them thoughtfully with evidence-based vaccination education campaigns provided by trusted health care professionals throughout the ranks.

Mary Wootan Holst holds a B.S. in English from the United States Naval Academy. She is currently pursuing a Doctorate of Medicine at UT Health Science Center San Antonio Long School of Medicine. She is interested in pediatric medicine and community and public health.

\section{Bibliography}

1. Afrough, B., S. Dowell, and R. Hewson. 2019. "Emerging viruses and current strategies for vaccine intervention." Clinical and Experimental Immunology 196, no. 2 (April): 157-166. https://doi.org/10.1111/cei.13295.

2. Alliance for Securing Democracy. 2021. "Influence-enza: How Russia, China, and Iran Have Shaped and Manipulated Coronavirus Vaccine Narratives." Securing Democracy. https://securingdemocracy.gmfus.org/russia-chinairan-covid-vaccine-disinformation/.

3. Bigornia, Veronica E. 2021. "U.S. Navy Aircraft Carrier Prevents Outbreak at Sea in Midst of COVID-19." Mil Med. 186 (7-8): 178-180. doi: 10.1093/ milmed/usab107.

4. Che, Claire, ed. "China Calls For Halt to Mandatory Vaccines Amid Inoculation Push.” Bloomberg.com. Bloomberg, April 11, 2021. https://www. bloomberg.com/news/articles/2021-04-12/china-calls-for-halt-to-mandato ry-vaccines-amid-inoculation-push.

5. Cole, Jared P., and Kathleen S. Swendiman. 2014. Mandatory Vaccinations: Precedent and Current Laws. N.p.: Congressional Research Service. RS21414. 
6. Coughlan, Lynda. 2020. "Factors Which Contribute to the Immunogenicity of Non-replicating Adenoviral Vectored Vaccines." Frontiers in Immunology, (May). https://doi.org/10.3389/fimmu.2020.00909.

7. Dube, Eve, Caroline Laberge, Paul Bramadat, Real Roy, and Julie A. Bettinger. 2013. "Vaccine Hesitancy." Human Vaccines and Immunotheraputics 9, no. 8 (April): 1762-1773. https://doi.org/10.4161/hv.24657.

8. Forgey, Quint. 2021. "Pentagon: 70 percent of service members have received first dose of Covid vaccine." Politico, July 16, 2021. https://www.politico.com/ news/2021/07/16/military-coronavirus-vaccine-499822.

9. Guest, Jodie L., Carlos d. Rio, and Travis Sanchez. 2020. “The Three Steps Needed to End the COVID-19 Pandemic: Bold Public Health Leadership, Rapid Innovations, and Courageous Political Will." JMIR Publications 6, no. 2 (April). 10.2196/19043.

10. Headquarters, Departments of the Army, the Navy, the Air Force, and the Coast Guard. 7 October 2013. Army Regulation 40-562. Immunizations and Chemoprophylaxis for the Prevention of Infectious Diseases.

11. Immunization Action Coalition. 2021. "Vaccine Timeline." Historic Dates and Events Related to Vaccines and Immunization. https://www.immunize. org/timeline/

12. "Immunization Coverage." World Health Organization. World Health Organization. Accessed August 6, 2021. https://www.who.int/news-room/factsheets/detail/immunization-coverage.

13. Kasper, M. R., J. R. Geibe, C. L. Sears, A. J. Riegodedios, T. Luse, A. M. Von Thun, M. B. McGinnis, et al. n.d. "An Outbreak of Covid-19 on an Aircraft Carrier.” N Engl J Med 2020 Dec 17;383(25):2417-2426. doi: 10.1056/NEJMoa20193752020 Dec 17;383(25):2417-2426.

14. Lang, Michael A., Shauna Stahlman, Natalie Y. Wells, and Et Al. 2021. "Disparities in COVID-19 Vaccine Initiation and Completion Among Active Component Service Members and Health Care Personnel, 11 December 2020-12 March 2021." MEDICAL SURVEILLANCE MONTHLY REPORT 28, no. 4 (APR): 2-9. PMID: 33975434.

15. Litvinova, Daria. "Russia Mandates VaccinationsforSomeas VirusCasesSurge." AP NEWS. Associated Press, June25,2021.https://apnews.com/article/europe- 
russia-health-coronavirus-pandemic-business-42d0c14f0545371e16a360b $677 \mathrm{cb} 4 \mathrm{c} 38$.

16. MacDonald, Noni E. 2015. "Vaccine hesitancy: Definition, scope and determinants." Science Direct 33, no. 34 (April): 4161-4164. https://doi.org/10.1016/j. vaccine.2015.04.036.

17. Manfred, Lenzen, Li Mengyu, Malik Arunima, Francesco Pomponi, and Ya-Yen Sun. 2020. "Global socio-economic losses and environmental gains from the Coronavirus pandemic." PLOS One 15 (7). https://journals.plos.org/ plosone/article?id=10.1371/journal.pone.0235654.

18. Montgomery, Jay, and Margaret Ryan. 2021. "Myocarditis Following Immunization With mRNA COVID-19 Vaccines in Members of the US Military." 10.1001/jamacardio.2021.2833 ed. JAMA Cardiology.

19. Newkirk II, Vann R. 2016. "A Generation of Bad Blood." The Atlantic, JUNE 17, 2016. https://www.theatlantic.com/politics/archive/2016/06/tuskegee-stu dy-medical-distrust-research/487439/.

20. Nguyen, Kimberly H., Anup Srivastav, Hilda Razzaghi, Walter Williams, Megan C. Lindley, Cynthia Jorgensen, Neetu Abad, and James A. Singleton. 2021. "COVID-19 Vaccination Intent, Perceptions, and Reasons for Not Vaccinating Among Groups Prioritized for Early Vaccination - United States, September and December 2020." Morbidity and Mortality Weekly Report 70 (6): 217-222. https://www.cdc.gov/mmwr/volumes/70/wr/mm7006e3.htm\#suggestedcitation.

21. Pardi, Norbert, Michael J. Hogan, Frederick W. Porter, and Drew Weissman. 2018. "mRNA vaccines - a new era in vaccinology." Nature Reviews Drug Discovery 17 (January): 261-279. https://doi.org/10.1038/nrd.2017.243.

22. Payne, Daniel C., Sarah E. Smith-Jeffcoat, and Gosia Nowak. 2020. "SARSCoV-2 Infections and Serologic Responses from a Sample of U.S. Navy Service Members - USS Theodore Roosevelt, April 2020.” MMWR Morbidity and Mortality Weekly Report 69 (23): 714-721. https://www.ncbi.nlm.nih.gov/ pmc/articles/PMC7315794/.

23. Roos, Robert. 2003. "Judge orders DoD to stop requiring anthrax shots." Center for Infectious Disease Research \& Policy. https://www.cidrap.umn.edu/ news-perspective/2003/12/judge-orders-dod-stop-requiring-anthrax-shots.

24. S, Tregoning J. 2020. "Vaccines for COVID-19." Clinical and Experimental Im- 
munology 202, no. 2 (September): 162-192. https://doi.org/10.1111/cei.13517.

25. Sabin Vaccine Institute and The Aspen Institute. 2020. "Meeting the Challenge of Vaccination Hesitancy." Sabin-Aspen report 2020, (May). https:// assets.aspeninstitute.org/content/uloads/2020/06/sabin-aspen-report-2020_ meeting_the_challenge_of_vaccine_hesitancy.pdf?_ga $=2.242091585 .23$ 6896274.1591219234-1140465311.1590185549.

26. Sandbrink, Jonas B., and Robin J. Shattock. 2020. "RNA Vaccines: A Suitable Platform for Tackling Emerging Pandemics?” Front Immunol 11, no. 608460 (December). 10.3389/fimmu.2020.608460.

27. South, Todd. 2021. "Troops who refused anthrax vaccine paid a high price." Military Times. https://www.militarytimes.com/news/pentagon-congress/20 21/06/17/troops-who-refused-anthrax-vaccine-paid-a-high-price/.

28. U.S. Food and Drug Administration. 2021. "Emergency Use Authorization." U.S. Food and Drug Administration. https://www.fda.gov/emergency-pre paredness-and-response/mcm-legal-regulatory-and-policy-framework/ emergency-use-authorization.

29. U.S. National Library of Medicine. 2013. "Smallpox: a great and terrible scourge." History of Medicine. https://www.nlm.nih.gov/exhibition/small pox/sp_variolation.html.

30. Watson, Rachel E., Taylor B. Nelson, and Albert L. Hsu. 2021. "Fertility Considerations: The COVID-19 disease may have a more negative impact than the COVID-19 vaccine, especially among men." (March). https://www. fertstertdialog.com/posts/fertility-considerations-the-covid-19-diseasemay-have-a-more-negative-impact-than-the-covid-19-vaccine-especiallyamong-men?room_id=871-covid-19.

31. "WHO and UNICEF Warn of a Decline in Vaccinations During Covid-19." World Health Organization. World Health Organization. Accessed August 6, 2021. https://www.who.int/news/item/15-07-2020-who-and-unicef-warn-ofa-decline-in-vaccinations-during-covid-19. 